\title{
Paleoenvironmental evolution of the Itararé Group (Paraná Basin) in the REgions of SAlto and Itu, EASt of São Paulo State, Brazil
}

\author{
SÉrgio Bergamaschi ${ }^{1}{ }^{*}$, Renata Marins Alvim Gama de Oliveira ${ }^{1}$, Victor Matheus JoAQUim Salgado Campos ${ }^{2}$, \\ Gabriel Paravidini de Souza ${ }^{2}$, Gabrielle Ferreira Pinto ${ }^{2}$, Pedro Correia Pessano ${ }^{2}$, Marcus Vinícius Berao \\ Ade $^{1}$, André Eduardo Piacentini Pinheiro ${ }^{3}$, MARia Virgínia Alves Martins $^{1,4}$
}

1 Universidade do Estado do Rio de Janeiro, Faculdade de Geologia, Departamento de Estratigrafia e Paleontologia. Rua São Francisco Xavier, 524, sala 2020A, Maracanã, 20550-013, Rio de Janeiro, RJ, Brazil.sergioberg7@hotmail.com, renata.oliveira@uerj.br, marcus.ade@uerj.br, virginia.martins@ua.pt

2 Undergraduate students of Universidade do Estado do Rio de Janeiro, Faculdade de Geologia. Rua São Francisco Xavier, 524, Maracanã, 20550-013, Rio de Janeiro, RJ, Brazil.victorsalgadocampos@hotmail.com, paravidini013@gmail.com, gabrielle_ferreirap@hotmail.com, ppessano@gmail.com

3 Departamento de Ciências (DCIEN), Faculdade de Formação de Professores (FFP), Universidade do Estado do Rio de Janeiro (UERJ), Rua Francisco Portela, 1470, Patronato, 24435-005, São Gonçalo, RJ, Brazil. paleolones@yahoo.com.br

4 Unidade de Investigação GeoBioTec, Departamento de Geociências, Universidade de Aveiro, 3810-193 Aveiro, Portugal.

*Corresponding AUthor, sergioberg7@hotmail.com

Received on 02 February 2016

Received in revised form on 07 March 2016

Accepted on 09 March 2016

Editor:

Herminio Ismael de Araújo-Júnior, Universidade do Estado do Rio de Janeiro, Brazil
Citation:

Bergamaschi, S., Oliveira, R.M.A.G., Campos, G.F., Souza, V.M.J.S., Pinto, G.P., Pessano, P.C., Ade, M.V.B., Pinheiro, A.E.P.P., Martins, M.V.A., 2016. Paleoenvironmental evolution of the Itararé Group (Paraná Basin) in the regions of Salto and Itu, East of São Paulo State, Brazil. Journal of Sedimentary Environments, $1(1): 139-152$.

\section{Abstract}

Itararé Group represents the glacial record of Gondwana Continent in the intracratonic Paraná Basin, encompassing regions of Southern Brazil, Eastern Paraguay, Northeast Argentina and Northern Paraguay. Itararé Group is the thickest sedimentary package of Paraná Basin, and was deposited over 36 million years during the end of the Carboniferous and the beginning of the Permian. However, in relation to its paleoenvironmental evolution, it is generally understood that more research is necessary, in order to better understand the genesis of the Itararé Group in different places.

The present work entailed mapping facies associations for the Itararé Group in the city of Salto, in São Paulo State, by identifying and classifying sedimentary facies that, in turn, were utilized to develop a paleoenvironmental evolution model. This model was based on geological mapping carried out over $125 \mathrm{~km}^{2}$. Petrological and petrographic descriptions of 32 outcrops of Itararé Group also were studied. These results were compared with subsurface data obtained by Sistema de Informações de Águas Subterrâneas, Serviços Geológicos do Brasil (SIAGAS-CPRM; System Water Information Groundwater, Geological Survey of Brazil). Through lithofacies and petrographic analyses and making a comparison between five column sections, surface and subsurface data, a stratigraphic correlation model was established for the region. Through this model was possible to identify four facies associations, which, together, indicate how the paleoenvironmental evolution of the region occurred. The first three associations (A, B, C) were interpreted as being formed in subaqueous environment, being related to sandy lobe systems, followed by the last association (D), pertaining to a fluvial system.

Keywords: Facies. Geological mapping. Gondwana supercontinent. Permo-Carboniferous glaciation. paleoenvironmental reconstruction 


\section{Introduction}

The Itararé Group is a record of the PermoCarboniferous glaciation of the Gondwana paleocontinent (Gordon Jr., 1947) which controlled the sedimentary infill of Paraná Basin (Suss et al., 2014).

The Paraná Basin is located in the South American Continent (Fig. 1A) and comprises a sedimentary area of approximately 1.5 million square kilometers encompassing regions of Southern Brazil, Eastern Paraguay, Northeast Argentina and Northern Paraguay. It is an oval intracratonic basin with approximately 7,000 meters of maximum thickness, whose major axis has a N-S direction. Its oldest strata are Ordovician and the most recent were deposited during the Late Cretaceous (Milani et al., 2007).

The Itararé Group consists of shale, sandstone, conglomerate and diamictite overlapping the Pre-Cambrian basement. In the study area, these sediments are not deformed tectonically although regional folding is common in other regions. The Itarare Group represents the glacial sedimentary record of the ancient Gondwana supercontinent, and is the thickest sedimentary package of the Paraná Basin, deposited in the late Carboniferous and early Permian, over approximately about 36 million years (França and Potter, 1988). It was formally divided by França and Potter (1988) into the Lagoa Azul, Campo Mourão, Taciba and Aquiduana formations (Fig. 1B).

Lagoa Azul Formation, at the base of the Itararé Group, was deposited during the Late Carboniferous as indicated by pollen analysis by Daemon and Quadros (1970). It consists of gray sandstones, siltstones and mudstone pebbles and occurs over an area of $480,000 \mathrm{~km}^{2}$, overlapping the Devonian age Paraná Group, in some areas, and the crystalline basement in other zones, such as in the study area (Fig. 1A). Campo Mourão Formation, discordant of Lagoa Azul Formation and approximately $640,000 \mathrm{~km}^{2}$ in area, is located in the intermediate portion of the Itararé Group. It consists of sandstones, conglomerates, conglomeratic sandstones, siltstones and mudstones pebbles.

Taciba Formation is the upper portion of the Itararé Group and occupies much of the outcrop unit (Fig. 1B). It covers an area of $710,000 \mathrm{~km}^{2}$ and is of Permian age, according to Daemon and Quadros (1970). Finally, Aquidauana Formation, which is characterized by the presence of reddish sandstone, is outcropping in Mato Grosso do Sul (Fig. 1A).

However, the Itararé Group is not yet completely known, and the paleoenvironmental evolution that led to its formation is not yet fully understood. Thus, more research such as that of Vesely and Assine (2004) and Arab et al. (2009), in different locations, is needed for a better understanding of the Itararé Group genesis.

This work aims to study the depositional environment of the Itararé Group of the Paraná Basin through the identification, classification and mapping of sedimentary facies associations outcropping in the region of Salto, São Paulo State, Brazil. This information was used to prepare a paleoenvironmental evolution model.

\section{Materials and Methods}

The filed work was carried out in June 2015, in an area of $125 \mathrm{~km}^{2}$. During the field work, outcrops of the Itararé Group at 32 sites in the region of Salto, São Paulo State, Brazil were described, georeferenced and studied (Fig. 2 and Tab. 1). Data were collected, focusing on the petrological analysis of the lithology of sedimentary rocks, facies descriptions and recognition of facies successions of outcropping units (Tab. 2).

Subsurface data, from three well logs collected in the central-eastern portion of the study area were used in the characterization of columnar sections, in stratigraphic correlations, and subsequently in the conception of the map of the facies association. These data are available online from technical reports of groundwater exploration wells for agricultural or domestic use from "Sistema de Informações de Águas Subterrâneas, Serviços Geológicos do Brasil" (SIAGAS-CPRM; System Water Information Groundwater, Geological Survey of Brazil; Fig. 2; Tab. 3).

Three thin sections (laminas to be used for optical microscopy) were also prepared in the sample processing geological laboratory (Laboratório Geológico de Preparação de Amostras - LGPA) of UERJ, by impregnating liquid resin with catalyst and blue dye, in order to identify rock pores.

The map of the facies association was drawn with the ArcGIS 10.2.2 software (Fig. 2). The study area is the $23 \mathrm{~K}$ in the American system of UTM coordinates (datum: Córrego Alegre).

\section{Results}

\subsection{Sedimentary facies: description and classification}

Facies of the lithologies observed in the field have been identified (Tab. 2; Fig. 3), and described and according to the code established by Miall (1978) with adaptations for the study area, as follows: 


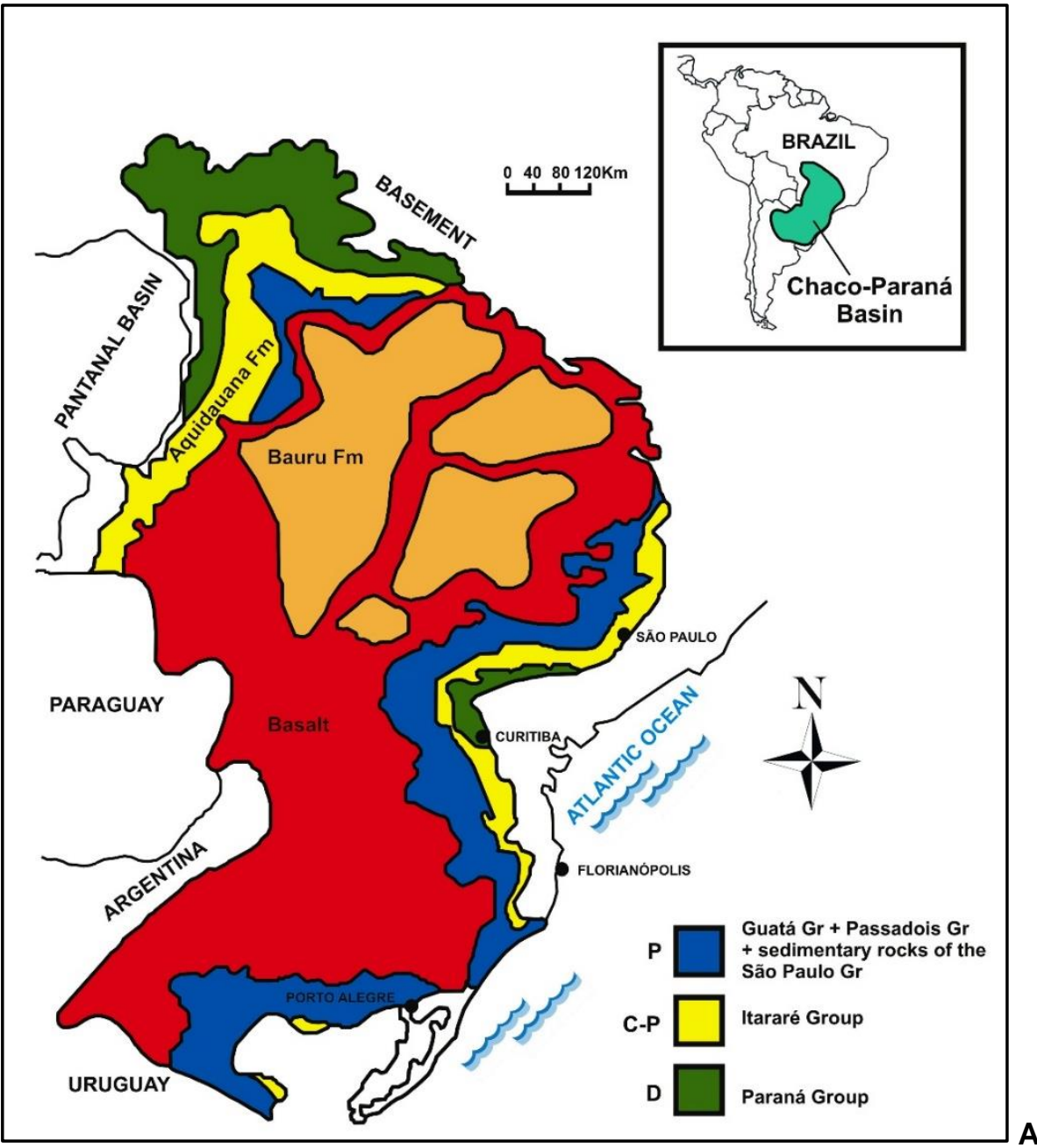

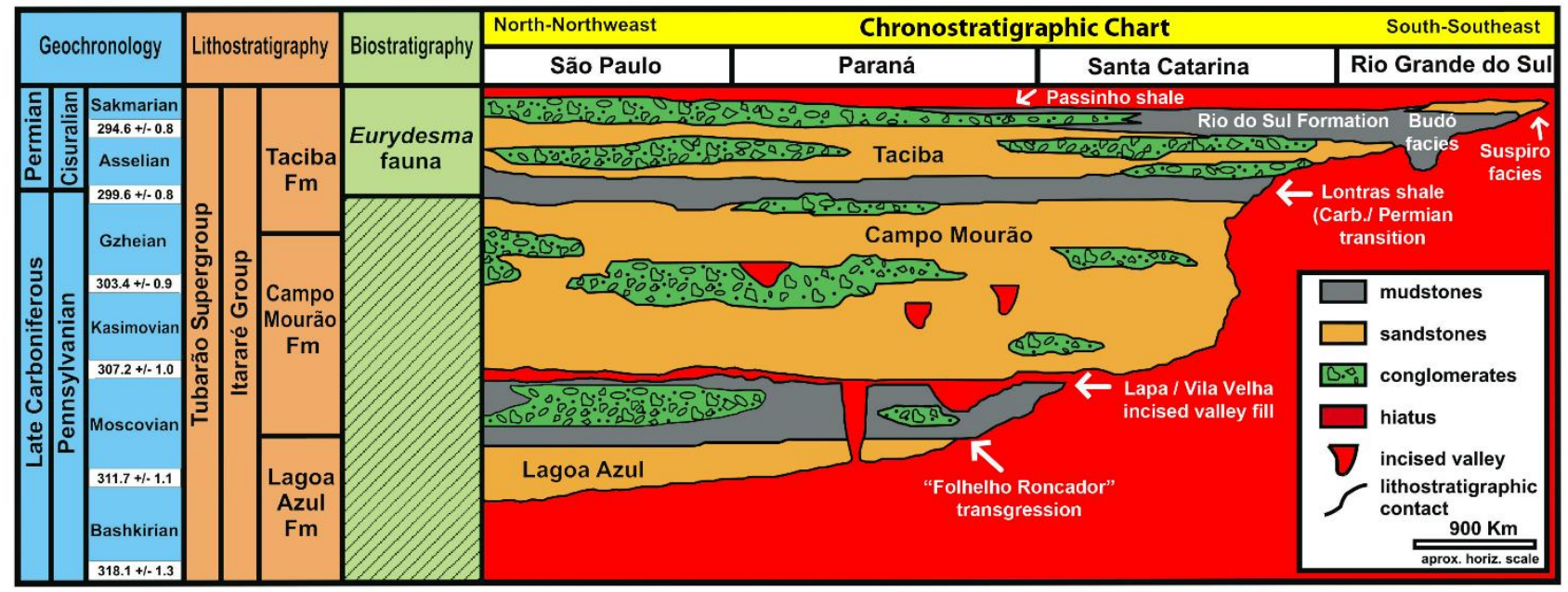

Fig. 1. A - Geologic map of Paraná Basin with the division of lithostratigraphic units and the study area (adapted from Milani, 1997). B - Chronostratigraphic chart of the Late Paleozoic in Paraná Basin (Itararé and Guatá groups), modified of Holz et al. (2010). 


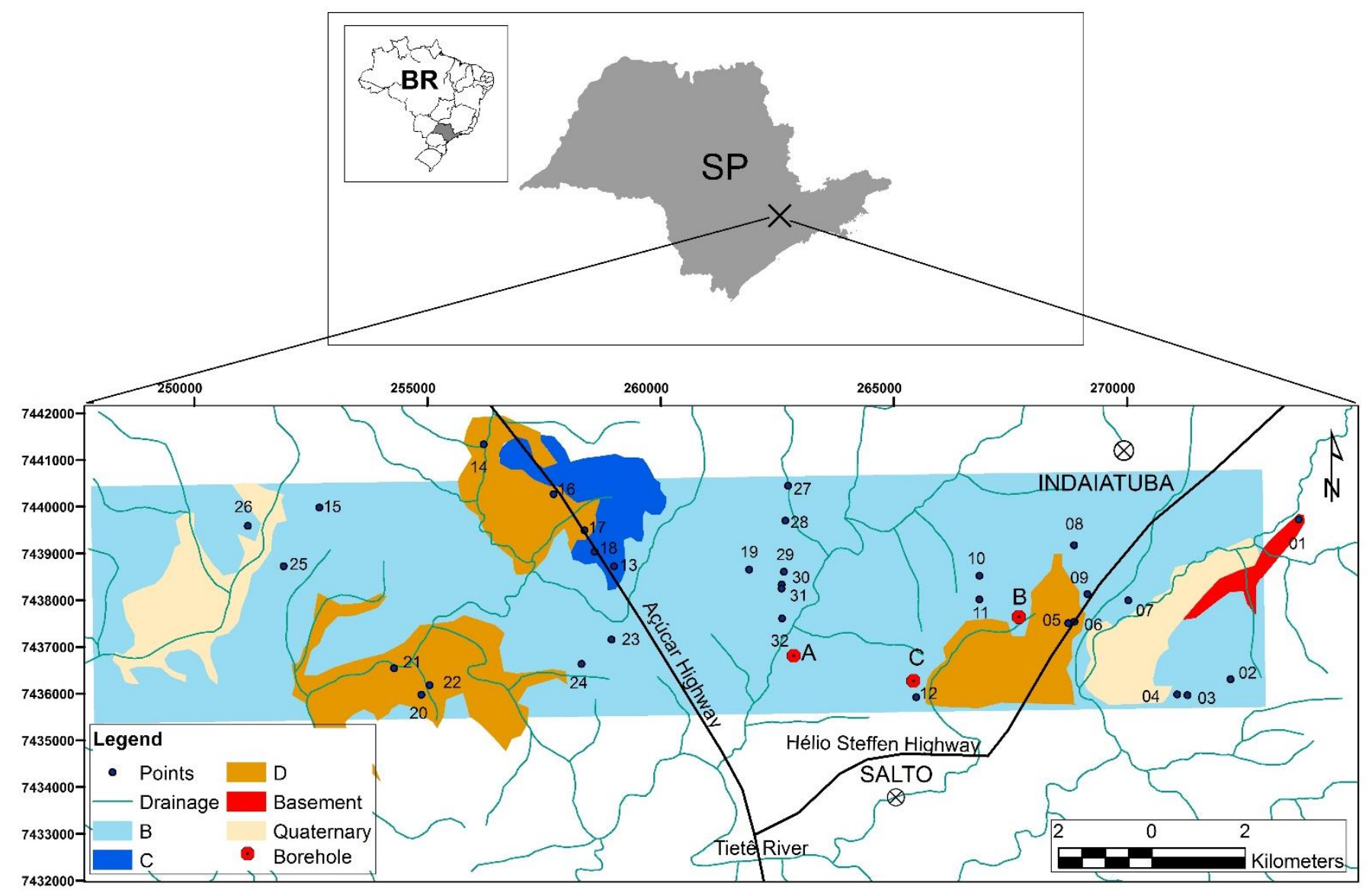

Fig. 2. The study area in São Paulo State (SP), Brazil (BR). Location of the 32 studied sites (Tab. 1) of the Itararé Group rocks outcropping in the study area are presented. The boreholes available from SIAGAS-CPRM are signed with red balls (A-C). The shaded areas in the map corresponds to Facies Association B (light blue), Facies Association C (dark blue) and Facies Association D (brown). The Facies Association $\mathrm{A}$ is not represented in this map, since it mainly occurs in the subsurface sedimentary layers.

Massive diamictite (Dm). Diamictite with a silty-clay matrix and rounded and/or angular polymictic clasts with particle size equivalent to gravel or pebble, arranged randomly in the matrix. This facies has a tabular or sigmoidal external geometry and a massive internal structure (Fig. 3A).

Massive or with incipient lamination sandstone (Smm). Sandstone composed of fine to medium sand grain size. It is beige colored and is composed of sub-rounded quartz grains with high sphericity, and a clay matrix, and occasionally by manganese oxide precipitations. It is characterized by a tabular external geometry and massive internal structure or incipient plane-parallel lamination. This facies is the most common in the study area (Fig. 3C).

Conglomeratic sandstone with incipient lamination (Gp). This facies is beige colored and is characterized by a fine arcosean sandstone including some oblate clasts. It exhibits an external tabular geometry and an incipient paleoparallel lamination (Fig. 3A, below; Figs. 3B, 3C, above).

Sandstone with trough cross-bedding $(\mathrm{St})$. This is a beige colored sandstone composed mainly of quartz grains with mean sand size. This facies exhibits a tabular external geometry, festoon (trough) cross-bedding and erosional truncation (Fig. 3D).

Sandstone with cut-and-fill structure (Ss). This is a beige arcosean sandstone composed predominantly of quartz, with particles grain size equivalent to medium sand. The external geometry is characterized by bed forms outlined by erosion. The internal structure is massive but exhibits centimeter globules of clay cemented by iron oxide. Such balls may have been removed from the substrate and assimilated into the sediment flow. 

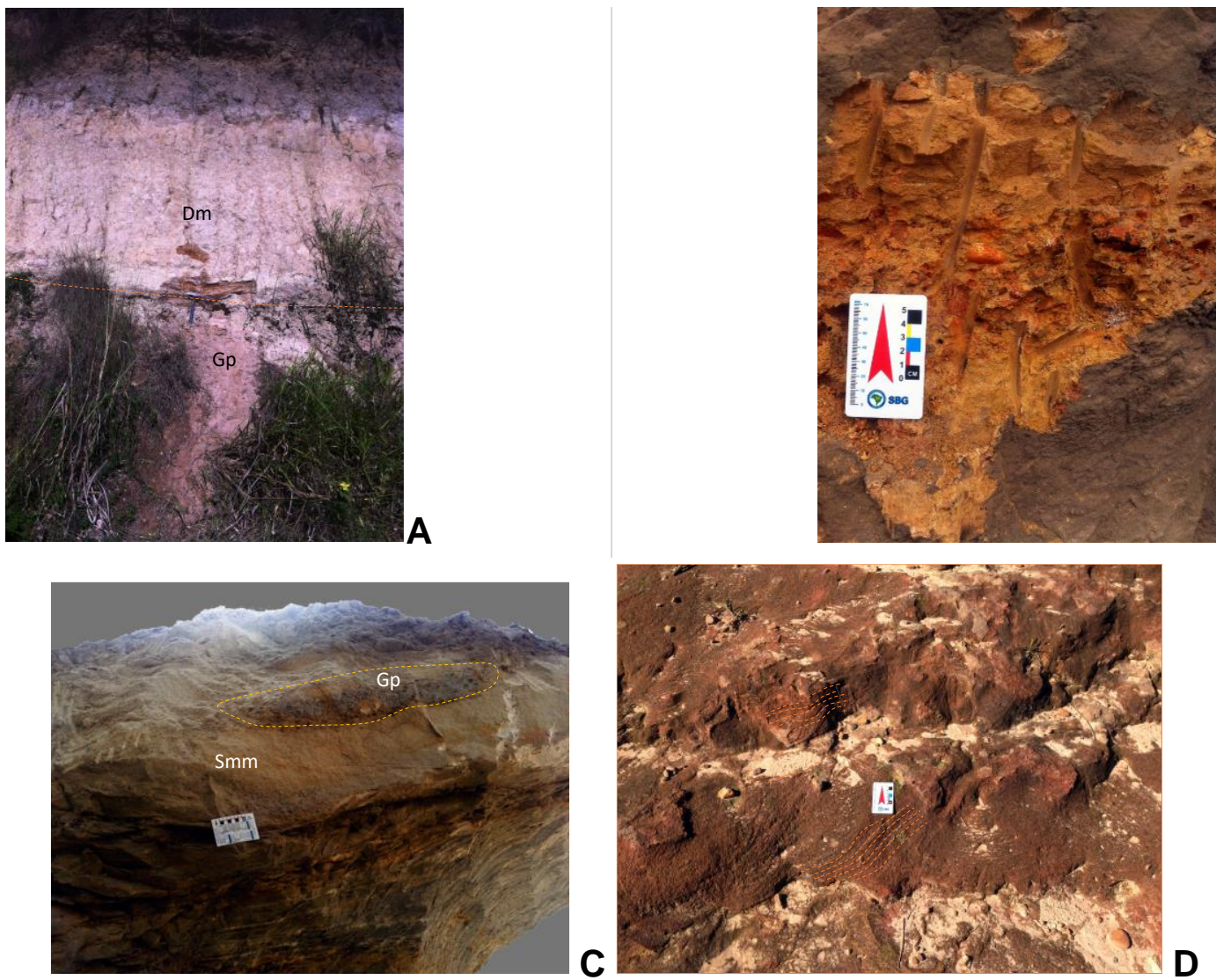

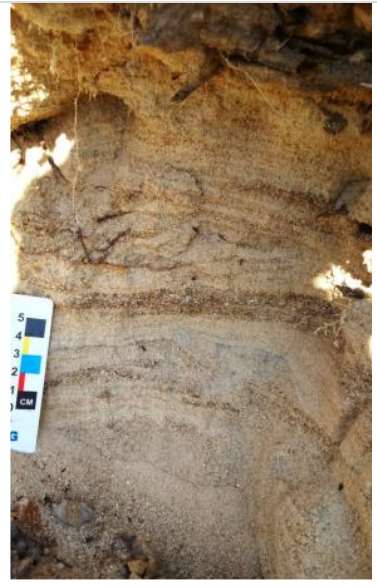

E

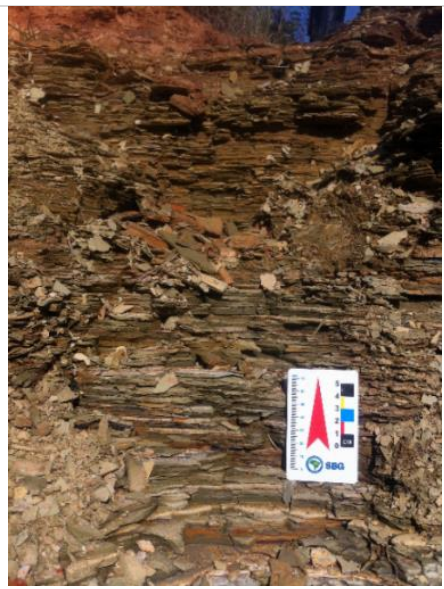

$\mathbf{F}$

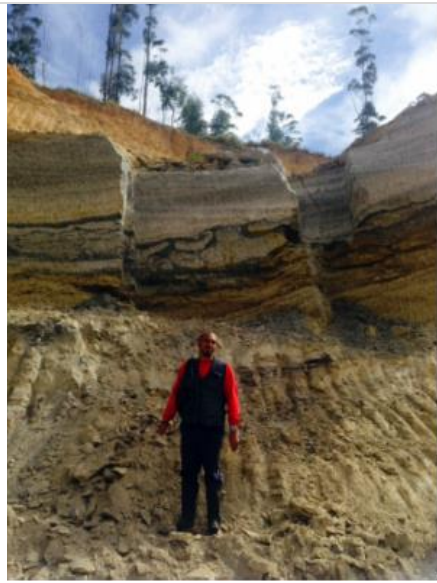

G

Fig. 3. Photos showing various facies that outcrop in the study area. A. Facies Dm - massive diamictite over a Facies Gp, a conglomeratic sandstone with incipient lamination. B. Facies Gp - fine sandstone with oblate pebbles on the granular band and incipient lamination. C. Facies Smm - massive sandstone, with occasional incipient lamination. Note the presence of conglomeratic sandstone lenses associated with higher energy flows, which will be further discussed. D. Facies St - sandstone with trough cross-bedding; this structure is indicated in the photo; this facies also has as erosive features, mudstone intraclasts and channel-bed structures. E. Facies Sp - medium sandstone with tabular cross-bedding. F. Facies Fl - laminated shale with dark color and usually with a slab texture as shown; it is associated with fine-grained sandstones with bioturbation and exhibit fossiliferous assemblages. G. Facies Fm - light gray siltstones interstratified with fine sandstone; this facies exhibits deformation structures, such as dish or overload structures related to the continuous flow of sediment into the basin. 
Tab. 2. Metric coordinates (UTM coordinates; datum: Córrego Alegre).

\begin{tabular}{|c|c|c|}
\hline Site & Latitude X & Longitude Y \\
\hline 1 & 273683 & 7439730 \\
\hline 2 & 272223 & 7436307 \\
\hline 3 & 271299 & 7435968 \\
\hline 4 & 271078 & 7435983 \\
\hline 5 & 268740 & 7437507 \\
\hline 6 & 268875 & 7437541 \\
\hline 7 & 270028 & 7437997 \\
\hline 8 & 268865 & 7439178 \\
\hline 9 & 269151 & 7438132 \\
\hline 10 & 266838 & 7438523 \\
\hline 11 & 266833 & 7438017 \\
\hline 12 & 265481 & 7435926 \\
\hline 13 & 259004 & 7438727 \\
\hline 14 & 256207 & 7441336 \\
\hline 15 & 252683 & 7439984 \\
\hline 16 & 257705 & 7440269 \\
\hline 17 & 258367 & 7439496 \\
\hline 18 & 258581 & 7439037 \\
\hline 19 & 261900 & 7438656 \\
\hline 20 & 254867 & 7435976 \\
\hline 21 & 254282 & 7436544 \\
\hline 22 & 255045 & 7436182 \\
\hline 23 & 258949 & 7437156 \\
\hline 24 & 258305 & 7436637 \\
\hline 25 & 251916 & 7438730 \\
\hline 26 & 251149 & 7439593 \\
\hline 27 & 262732 & 7440448 \\
\hline 28 & 262676 & 7439702 \\
\hline 29 & 262644 & 7438609 \\
\hline 30 & 262594 & 7438336 \\
\hline 31 & 262594 & 7438250 \\
\hline 32 & 262608 & 7437610 \\
\hline
\end{tabular}

Medium sandstone with tabular cross-bedding (Sp). It is characterized by white sandstone, composed of quartz grains with medium sand size and a clay matrix. The package has a tabular external geometry and cross-tabular internal structure (Fig. 3E).

Fine to medium sandstone with plane-parallel bedding (Sh). It is a beige sandstone which assumes a red color when altered. It is composed of fine to medium sand grains of quartz and some feldspar. The sediments are well selected, well rounded and with high sphericity. The external geometry of this sedimentary unit is tabular displaying an internal plane-parallel structure.
Laminated dark shale (Fl). Greenish or black laminated shale with millimetric to centimeter levels of fine to very fine sandstone, with little ripples generally evident (Figure 3F). Occasionally, some sandy layers evidence bioturbation. A fossiliferous record was observed in this facies.

Massive or with incipient lamination siltstone with sandy levels $(\mathbf{F m})$. This is a beige to gray siltstone, composed predominantly of clay sized sedimentary particles with interstratification of very fine sandstone and conglomeratic lenses. Its external geometry is tabular. Internally its structure is marked by a parallel lamination. The chemically altered layers exhibit a reddish or greenish color. It has deformation structures such as overhead marks, dish arrangements, pillows, pillars and slump structures (Fig. 3G).

\subsection{Results of petrographic analysis}

The petrography of three thin sections of rocks from three representative map points was analyzed and described according to Folk (1974). This analysis allowed the classification and description of the sedimentological and diagenetic processes involved in the deposition of these units. Facies and Facies Association of the petrography of three thin sections of rocks (laminas) from three representative map points of the study area (sites 6, 20,27; location in Tab. 1; Fig. 2) are presented in Table 4 and Figure 4. Descriptions of these laminas are presented below.

Lamina of Site 6. The rock exhibits sand fraction grains with dimensions ranging from 0.1 to $0.7 \mathrm{~mm}$ and a mode of $0.5 \mathrm{~mm}$. The sediment is immature and poorly sorted, composed of $40 \%$ quartz, 30\% matrix, 15\% feldspar, 10\% lithic fragments and 5\% cement and a few dispersed opaque minerals. The quartz grains are angular and have moderate sphericity (Fig. 4A, B). The grains have planar and interconnected contacts with intra- and intergranular fractures. Due to matrix dissolution, secondary porosity occurs. These structures indicate intense diagenesis with the formation of quartzose cement. Because of the chaotic distribution of grains the internal structure is compact without imbrications (Fig. 4A, B).

Lamina of Site 20. The sandstone rock has particle size ranging from 0.1 to $1 \mathrm{~mm}$, with a mode of $0.3 \mathrm{~mm}$. The sediment is immature and poorly sorted, consisting mostly of $50 \%$ quartz, $10 \%$ feldspar, $5 \%$ of other lithic grains, $30 \%$ matrix and $5 \%$ cement. The quartz grains are rounded and have moderately good sphericity (Fig. 4C, D). Most grains are immersed in the matrix, but have some punctual contacts. Intergranular fractures probably caused by 
sediment transport can be observed. The rock has full gradation and imbricated grains (Fig. 4C, D).

Lamina of Site 27. The rock is composed of sand particles with size ranging from 0.2 to $1.3 \mathrm{~mm}$, with a mode of $0.4 \mathrm{~mm}$. The sediment is immature and poorly selected, consisting of $60 \%$ quartz, $20 \%$ feldspars, $15 \%$ matrix and
$5 \%$ lithic fragments. The quartz grains are moderately rounded and have moderate sphericity (Figs. 4E, 4F). The grains are immersed in matrix, or have specific contacts.

Dissolution or intragranular fracture structures were observed. The rock has a compact structure and does not have imbricated grains (Figs. 4E, 4F)

Tab. 2. General characteristics of the sedimentary facies found in the study area.

\begin{tabular}{lcc}
\hline Facies & Code of facies & Sites \\
\hline Massive diamictite & Dm & 7,12 \\
Massive or with incipient lamination sandstone with matrix & Smm & $4,5,6,7,14,16,18,19$, \\
Conglomeratic sandstone with incipient lamination & $\mathrm{Gp}$ & $21,25,27,28,30$ \\
Sandstone with trough cross-bedding & $\mathrm{St}$ & 31 \\
Sandstone with cut-and-fill structure & $\mathrm{Ss}$ & 6,9 \\
Medium sandstone with tabular cross-bedding & $\mathrm{Sp}$ & 6 \\
Fine to medium sandstone with plane-parallel bedding & $\mathrm{Sh}$ & $6,9,17$ \\
Laminated dark shale & $\mathrm{Fl}$ & $9,15,17,22,27,32$ \\
Massive or with incipient lamination siltstone with sandy levels & $\mathrm{Fm}$ & $6,13,18,20$ \\
Basement & ---- & $6,10,26,29,30$ \\
Quaternary & ---- & 1 \\
\hline
\end{tabular}

\subsection{Stratigraphic columns, stratigraphic correlation and facies association}

A panoramic photo obtained in the outcrop of site 6 (Tab. 1) is presented in Figure 5. The two most relevant stratigraphic columns, of two different outcrops of site 6 are presented in Figure 6. Through stratigraphic facies stacking it is possible to analyze facies successions, which facilitates the study of the lithofacies evolution of the region. Three well logs, of SIAGAS-CPRM (Tab. 3), at the eastern and central study area (Fig. 2; signed with A-C red balls) were analyzed, as well as five columnar sections from outcrops in the field (Fig. 7).

Through the study of the columnar sections of SIAGASCPRM based on the analysis of the wells refereed in Table 3, it was possible to deduce that the minimum thickness of the Itararé Group outcrop is 70 meters (well number \#350005289 stratigraphic column). The subsurface data reveal that the sedimentary package has no more than 143 meters thick in the eastern portion of the area (well number \#350005304 stratigraphic column) and at least 200 meters in the central-western portion (well number \#350005281 stratigraphic column).

The stratigraphic correlation (Figure 7) was based on the information obtained in the field and on subsurface data in order to reconstruct the depositional architecture of the Itararé Group in the study area. The top of facies Smm (Association B), related to subaqueous gravitational deposits that show good lateral continuity throughout the study area (Fig. 7), defines the correlation datum. There is evidence that little or no structural control affected the region, due to the low tectonic deformation (Hasui, 1984). This can also be deduced from the columnar sections, due to the lateral continuity of the strata of Associations A and B (see section 3.4). Therefore, it can be observed that the depositional architecture was influenced by the morphology of the basin. 

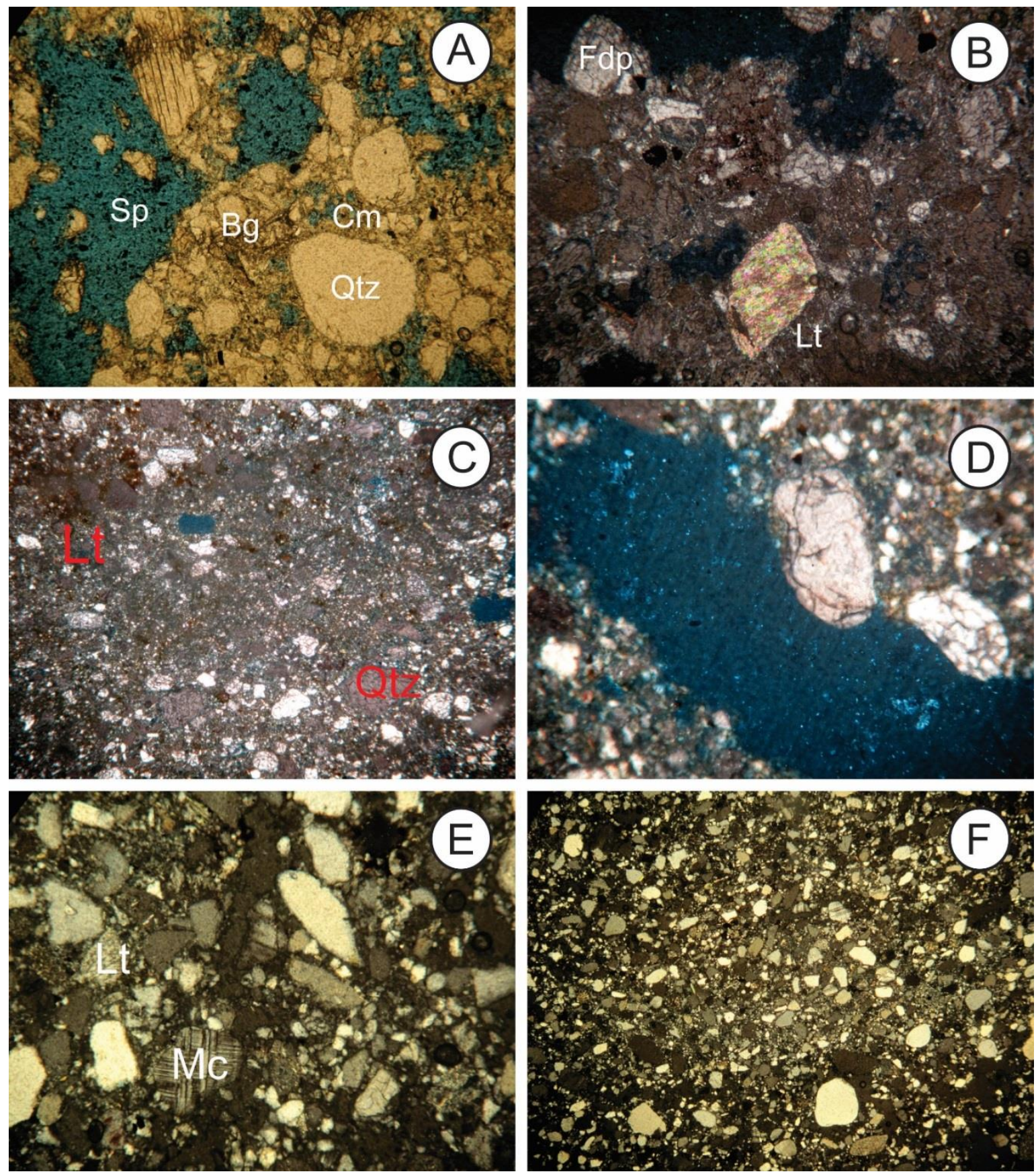

Fig. 4. Microscope photos of three thin sections of rocks. A. Lamina of Site 6 (coordinates in Table 1). Poorly sorted and immature sediment, with angular and moderate sphericity quartz grains (Qtz) and quartzose cement (Cm). The occurrence of secondary porosity evidenced by cement dissolution $(\mathrm{Sp})$ is indicated by the blue color in the image and also by the occurrence of broken grains (Bg), which are indicative of intense diagenesis. Parallel polarizers and 100x magnification. B. Lamina of Site 6 (coordinates in Table 1). The sedimentary rock is composed by lithic particles (Lt), namely feldspars (Fdp). The picture shows the secondary porosity in the upper portion, with some fractured quartz grains; crossed polarizers, 100x magnification. C. Lamina of Site 20 (coordinates in Table 1). Sediment has lithic fragments (Lt), such as feldspar (Qtz); the photo shows secondary porosity in the upper portion, with some fractured quartz grains; crossed polarizers, 100x magnification. D. Lamina of Site 20 (coordinates in Table 1). Poorly sorted sediment with normal gradation and imbricated grains; crossed polarizers, 50x magnification. E. Lamina of Site 27. Quartz growth around the grains (quartz overgrowth), consisting of rock cement; a grain of microcline (Mc) and lithic fragments (Lt) are indicated in the photo; crossed polarizers, 100x magnification. F. Lamina of Site 27. Poorly sorted sediment; crossed polarizers, 100x magnification. 


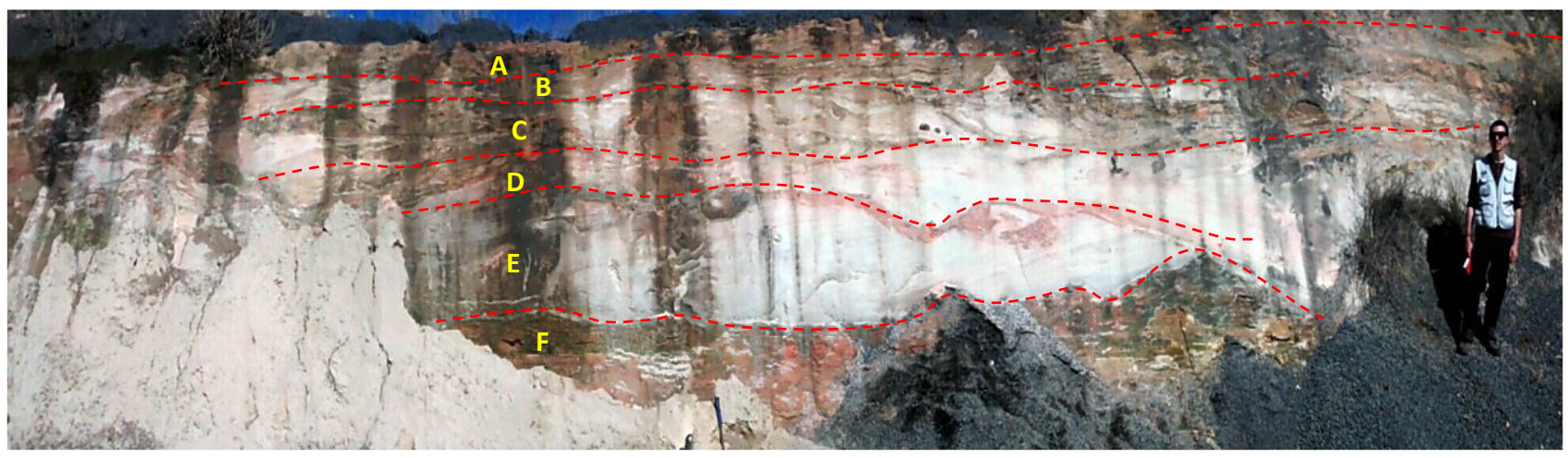

Fig. 5. Panoramic photo obtained in the outcrop site 6 (Tab. 1). A scale is included (man) and the facies (Table 2; see facies descriptions in the text) are marked (A-F). Legend: A. Shale with red color caused by chemical alteration (Facies Fl). Thickness: $50 \mathrm{~cm}$. B. Medium sandstone with tabular cross stratification and with intercalations of clay (Facies Sp). Thickness: $25 \mathrm{~cm}$. C. Medium white sandstone with trough cross-stratification and clay films (Facies St). Thickness: $50 \mathrm{~cm}$. D. Medium white fine sandstone with parallel lamination and erosive features (Facies Ss). Thickness: $150 \mathrm{~cm}$. E) Coarse sandstone with declining planar lamination (Facies Smm). Thickness: $90 \mathrm{~cm}$. F. Sandy siltstone, with reddish color due to chemical alteration, with internal structures of parallel lamination (Facies Fm). Thickness: $70 \mathrm{~cm}$.

A

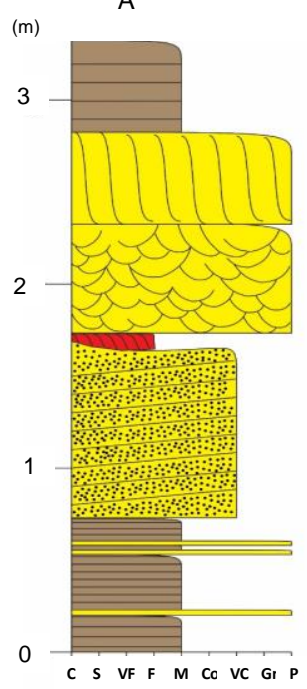

$\begin{array}{ll}\text { El } & \mathrm{Fl} \\ \text { IIII } & \mathrm{St} \\ \mathrm{Ss}\end{array}$
B

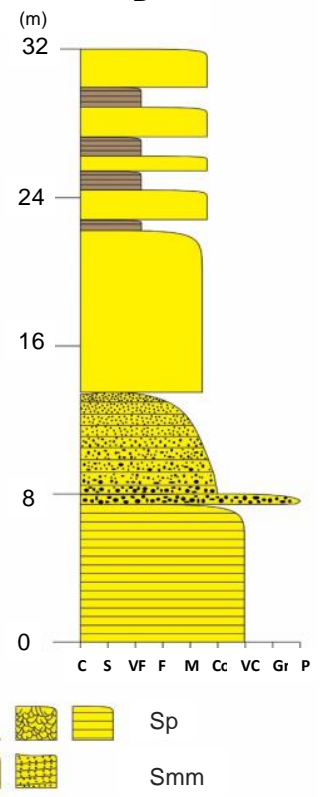

Fig. 6. Representation of the stratigraphic column facies (according to Table 2 and facies descriptions in the text) of two outcrops of site 6 ( $A$ and B). These outcrops are located in the map of Figure 2. Legend: Facies Fl - shale with red color caused by chemical alteration. Facies St - Medium white sandstone with trough cross-stratification and clay films. Facies Ss - Fine sandstone medium white with parallel lamination and erosive features. Facies Sp - Medium sandstone with tabular cross stratification and with intercalations of clay. Facies Smm - Coarse sandstone with declining planar lamination Granulometric scale (at the bottom of the stratigraphic columns): C - clay; S - silt; VF - very fine sand; F - fine sand; M - medium sand; Co - coarse sand; VC very coarse sand, $\mathrm{Gr}$ - granule and; $\mathrm{P}$ - pebble.

\subsection{Facies association}

Four facies associations were recognized and described in the Itararé Group in the study area, as described below.

Facies Association A consists of thick packages of medium grained sandstone that occurs mostly at the base of the columnar section 3 (Fig. 7), which gradually evolve to finer facies at the top in a retrogradational pattern.

Facies Association B occurs throughout the east-west profile, more significantly in parts of the eastern region, occasionally in São Manuel quarry, in some outcrops of the Açúcar Highway and along municipal road SLT-161. It is characterized at the base, by diamictite deposits with clay matrix and dispersed faceted pebbles (Dm). This facies is associated with conglomeratic sandstones with normal gradation $(\mathrm{Gp})$ and sandstones with sigmoidal geometries or tabular crossed structures (Sp). The diamictite is sometimes interbedded with sandstones encompassing plane-parallel lamination (Sh). These facies constitute finning-upward cycles (see columnar section 3, Fig. 7). At the top, there is compact gray siltstone interbedded with fine sandstone $(\mathrm{Fl})$.

Facies Association C is a geographically restricted deposit occurring only in the central portion of the study area. This association is characterized by the occurrence of black and/or greenish shales interbedded with thin sandstones exhibiting poorly defined ripples. This facies association was identified at km 108 of Açúcar Highway. It exhibits fossil-bearing assemblages, and sandstones with carbonate cement.

Facies Association D is characteristic of fluvial facies, and is composed of the following lithofacies: sandstone with plane-parallel stratification (Sh), sandstone with tabular 
cross-bedding (Sp) and sandstone with trough cross-bedding $(\mathrm{St})$. These deposits are located in the northeast area and their profile is best seen in the Açúcar Highway toll plaza. Mature, medium grain size sandstones are characteristic of these facies. These sandstones have sigmoidal and tabular geometries of channel fill and paleocurrents, typically stream-oriented from South to North. Outcrops of this facies association occur along state road SP-075, where it exhibits large fluted cross-laminations (Fig. 3D).

\section{DISCUSSION}

\subsection{Depositional environment model}

Sedimentation of the Itararé group is quite complex and involves several sedimentary environments. The presence of tillites and diamictites with many faceted and few striated clasts suggest that the study area was part of a glacial environment with relative proximity to the glacier. According to Assine and Vesely (2002, 2008), the sediments of the Itararé group were deposited in a retrogradationalprogradational regime and are a product of cycles of glacier advance and retreat in a glacio-marine environment. Arab et. al. (2009) associated the occurrence of tillites to a subglacial system, besides the glacio-marine environment.

Facies associations $\mathrm{A}, \mathrm{B}$ and $\mathrm{C}$ were interpreted as subaqueous gravity flow environments, fed by sediments from the melting glacier. The interbedding of the facies Gp, St and Smm is diagnostic of outwash fans, common in periglacial environments on the glacier margin (Vesely and Assine, 2004; Vesely, 2006), since it intercalates traditional facies with turbidite facies. The stacking has a retrogradational character with progradational pulses that evidence the retreat of the glacier, and thus a relative sea level rise.

Tab. 3. Location of three well logs, of SIAGAS-CPRM (metric coordinates (UTM coordinates; datum: Córrego Alegre). The stratigraphic column of these well logs are available in the following web addresses (Assessed at 29/06/2015): Well Number \#350005289 http://siagasweb.cprm.gov.br/layout/detalhe.php?ponto=3500005289; Well Number \#350005304 http://siagasweb.cprm.gov.br/layout/detalhe.php?ponto=3500005304; $\quad$ Well Number \#350005281 http://siagasweb.cprm.gov.br/layout/detalhe.php?ponto=3500005281

\begin{tabular}{ccccc}
\hline Well number & Locality & Latitude $\mathbf{X}$ & Longitude $\mathbf{Y}$ & Altitude (m) \\
\hline$\# 350005289$ & Fazenda Vesuvio & 267917 & 7437852 & 605 \\
$\# 350005304$ & Haras Albatroz & 265360 & 7435842 & 580 \\
$\# 350005281$ & - & 262694 & 7437000 & 530 \\
\hline
\end{tabular}

Progradational pulses are related to the presence of facies Gp and Smm with normal gradation, and poorly sorted and immature sediments (Fig. 4), which indicate unconfined turbulent flows associated with episodic melting and sediment flows into the basin. These facies are associated with sandy lobes in interchannel zones (Fig. 8), where continuous hyperpycnal turbulent flows predominate. This is evidenced by: the occurrence of thick, massive sandstone packages, generally over 1-meter-thick (Fig. 9); thick sandstone layers that evolve to pellitic layers (see columnar section 3 of Fig. 7); some sand layers without gradation and; the occurrence of dish or deformation structures in pellitic layers. These features indicate a high sedimentation rate in the basin over short time spans.

The term hyperpycnal is used for the Itararé Group according to the definition given by Vesely (2006). It is applicable to any subaqueous flow that comes out of the basin and enter it with a higher density than the basin fluid.
According to Vesely (2006), the hyperpycnite is originated in subaqueous flows from melting, that is, the glacier would have had water underneath its base. However, this could not be confirmed for the mapped area, since structures and facies related to subglacial systems, or near glaciers were not observed.

Facies Sp and St and the presence of erosive structures (cut and fill), identified as sand bar migrations, suggest channelized flows, which form submarine channels (distributive channels) at the base of the glacier. Facies Dm are associated with the base of these channels, morphologically similar to alluvial systems (Fig. 9, number 4). The occurrence of these facies is another factor that suggests that sediment loads were constant and of long duration. An important factor to be considered is the preservation of these subglacial channels, since facies Sp, St and Dm were considered subordinated in these associations, that is, they were not well preserved. Since the basin exhibits 
a high gradient (see columnar sections 1, 2 and 3 of Fig. 7), the channels may have been reworked by episodic turbulent flows.

The occurrence of facies Fl, clayey and silty, is related to decantation in more distal parts of the sedimentary system (Fig. 9, number 3). Decantation generally occurs along with episodic, high-energy flows, as suggested by the sandy and gravely lenses in the siltstone, and the interbedding of siltstone with fine sands. Wedge or lens shaped base structures also indicate channels. This interpretation is in accordance with Vesely (2006).

Tab. 4. Metric coordinates (UTM coordinates; datum: Córrego Alegre).

\begin{tabular}{lcc}
\hline Lamina & Facies & Facies Association \\
\hline Lamina of Site 6 & Smm & B \\
Lamina of Site 20 & St & D \\
Lamina of Site 27 & Gp & B \\
\hline
\end{tabular}

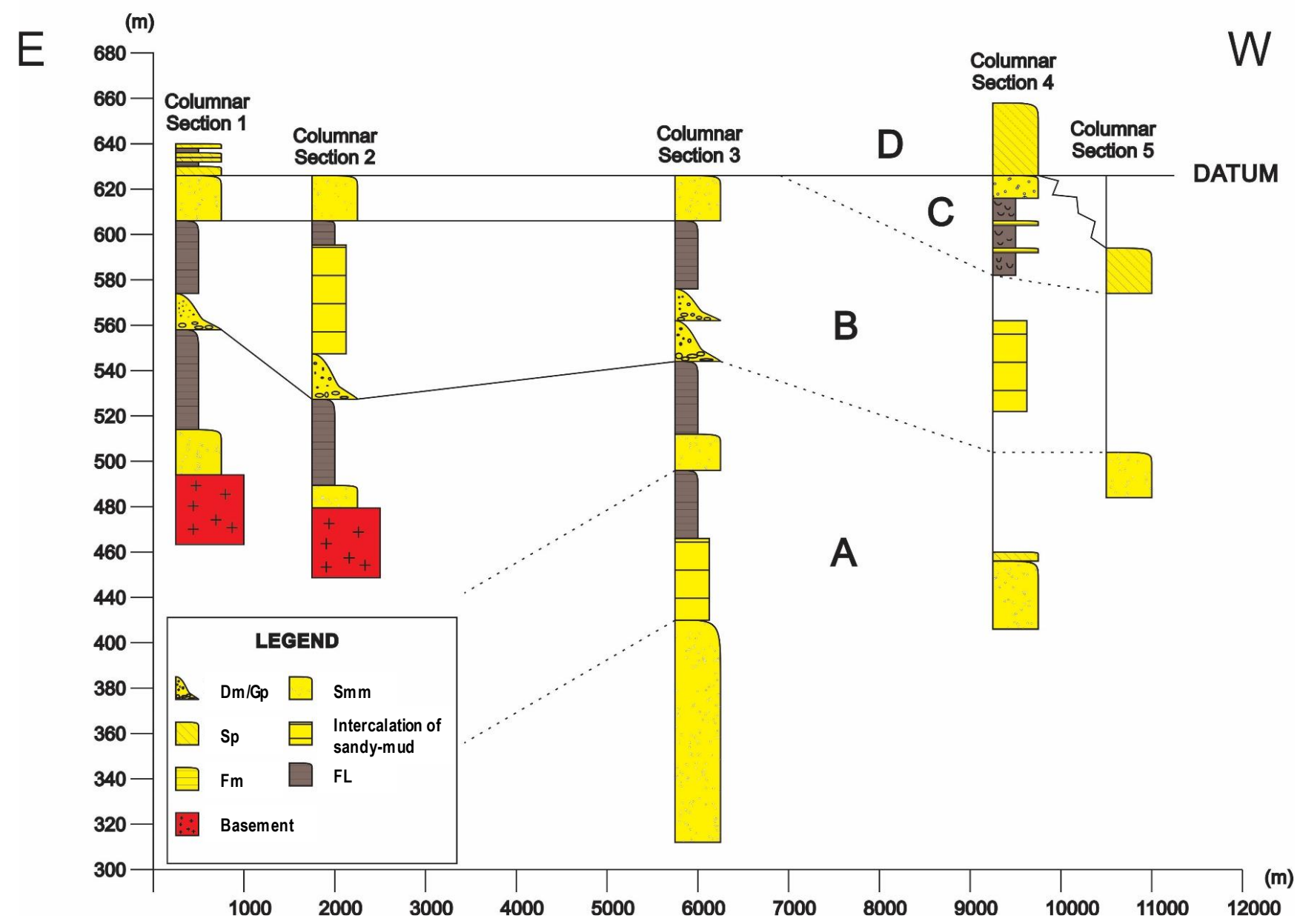

Fig. 7. Stratigraphic correlation of the sedimentary deposits of the Itararé Group in the study area. This correlation was obtained by the comparison between profiles made in the field and based on the interpretation of subsurface data. The facies associations analyzed in this work are presented the Figure 2.

Facies Association $\mathrm{C}$ is related to that depositional paleoenvironment, in more distal facies, due to the occurrence organic rich shale. This deposit must be analogous to the maximum flooding surface of the basin, however, it is a fossiliferous association in site 13, the outcrop that best represents this facies association.
Facies Association D overlies a discontinuity that limits associations A, B and C. This association contains facies Sp and St with features typical of channels: fining-upwards stacking, sediments with normal gradation, and imbricated grains (see laminas of Fig. 4C and 4D), suggesting fluvial processes. Fluvial processes are related to new glacier growth 
and stability, resulting in a lowering of the relative sea level and the consequent establishment of a glacio-fluvial system (Fig. 10). The deposits associated with these environments occur proximally in braided rivers (Fig. 10), as suggested by the collected paleocurrent data, shown in Figure 11. The Rosetta diagram for flow direction shows a flow tendency from South to North or from Southwest to Northeast, along the entire N-S profile of the area, suggesting low sinuosity for the channel, which is compatible with a braided fluvial system (Fig. 10).

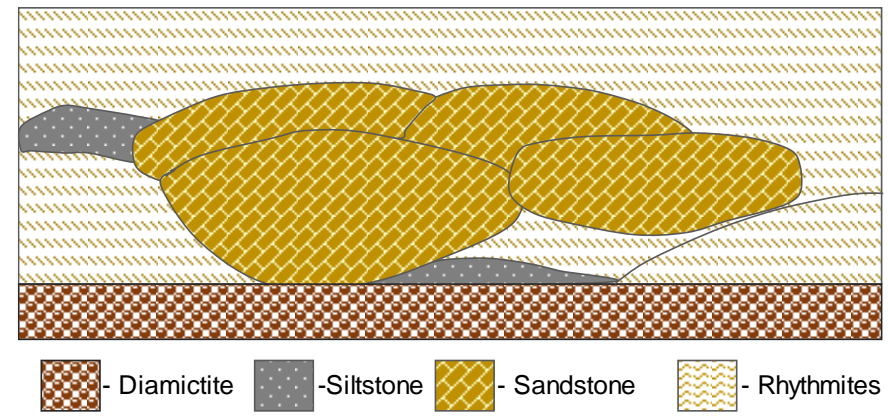

Fig. 8. Perpendicular section of sandy soils formed by hyperpycnal non-channeled flows. Modified from Mattos, 2012. Rhythmites are sedimentary layers related to fluxes and fine lithic materials deposited with noticeable periodicity and regularity.

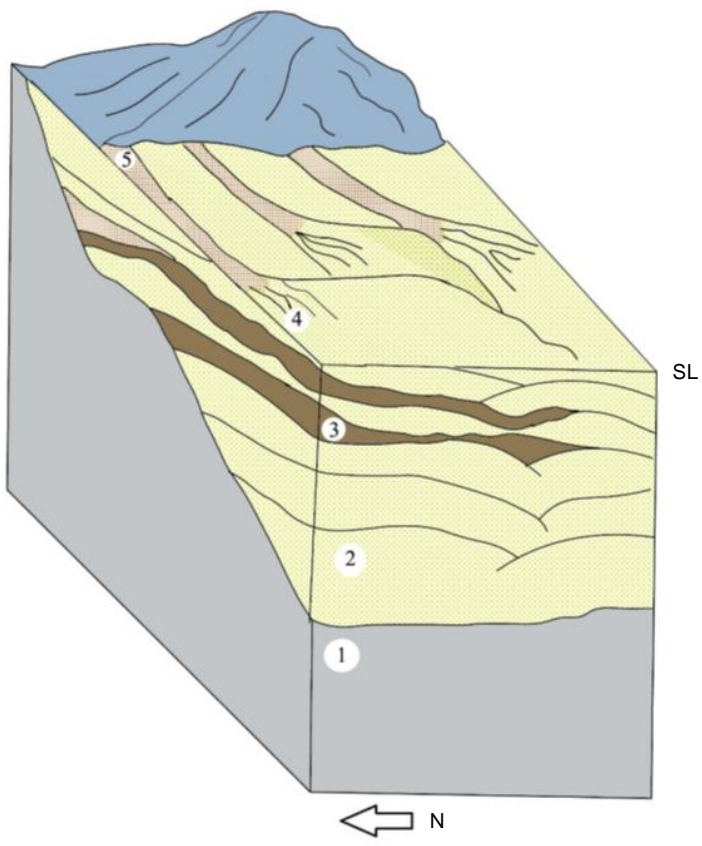

Fig. 9. Paleoenvironmental model of associations $\mathrm{A}$ and $\mathrm{B}$. Legend: 1 - Basement; 2 - Facies Smm deposited by unconfined hyperpycnal flows; 3 - Facies Fl deposited by decanting; 4 - Facies Sp and St, channeled sandstone flows; 5 - Facies Dm near the glacier; SL - sea level. Vertical scale $=1: 10$ meters; Horizontal scale $=1,500$ meters.
This paleoenvironment interpretation is in agreement with that suggested for the Campo-Mourão formation by França and Potter (1988), who describe a fluvial braided system utilizing subsurface data. However, it is not in agreement with the interpretation by Vesely (2006), who does not describe subaerial deposits for the Itararé Group. Mattos (2012) also does not recognize fluvial deposits in the facies associations of the Itararé Group, while focusing on the Eastern region of São Paulo state.

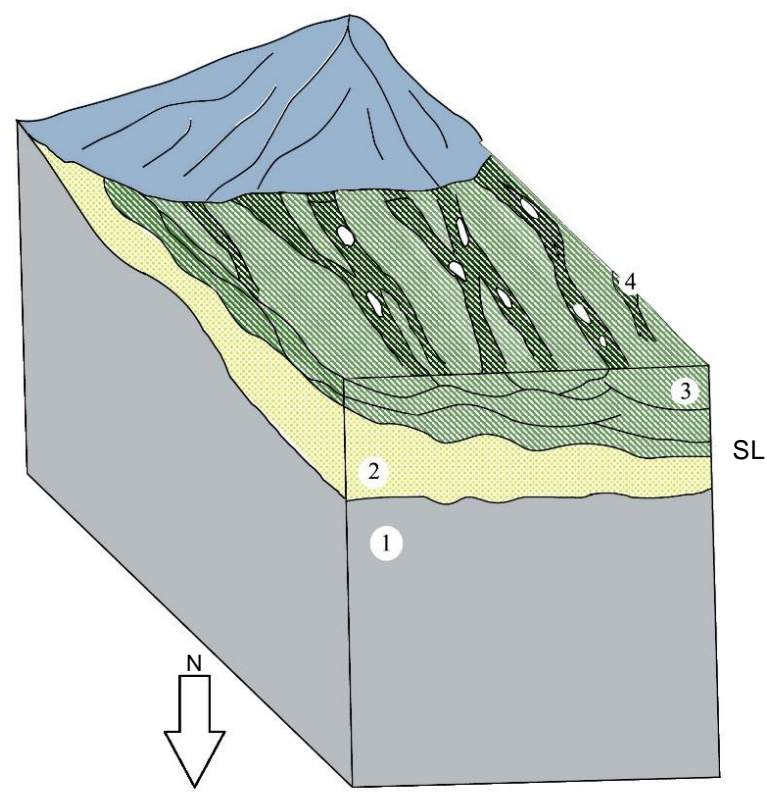

Fig. 10. Paleoenvironmental model of association D. Legend: 1 Basement; 2 - Deposits from subaqueous melting flows (Associations A and B); 3 - Glacio-fluvial deposits (Association D); 4 - Braided channels with sediment flow preferentially to the Northeast.

In the mapped area (Fig. 2), it is difficult to establish the precise position of the glacier, since there are no typical glacial deposits or structures such as glacial scouring. However, the position of the basement in the area, and the direction of high-density paleocurrent flows indicate that the glacier receded from Northwest to Southeast, remaining over the entire East and Southeast portion of the study area.

\section{Conclusion}

In associations $\mathrm{A}, \mathrm{B}$ and $\mathrm{C}$, proximal sandy lobes were identified. These sandy structures were originated by hyperpycnal or episodic flows into the basin, as well as distal glacio-marine sedimentation, represented by pelitic facies. Based on these interpretations, it may be inferred that the 
sedimentation in the study area was due to a glacio-marine environment related to the glacier receding.

It is suggested that during periods of melting, there was a relative sea level rise, releasing large sedimentary loads responsible for the high-density flows. These flows resulted in retrogradational stacking patterns, that is, distal facies overlaying the proximal facies.
RESEARCH PAPER

The results of this work are in agreement with what was interpreted for the Itararé Group in the literature. The fluvial facies are not well described, due to the absence of good outcrops, and to the lack of conclusive subsurface data for the study area. Thus, it is suggested that the analyses carried out herein be expanded geographically, and that new well data be acquired in the Salto (SP) region.

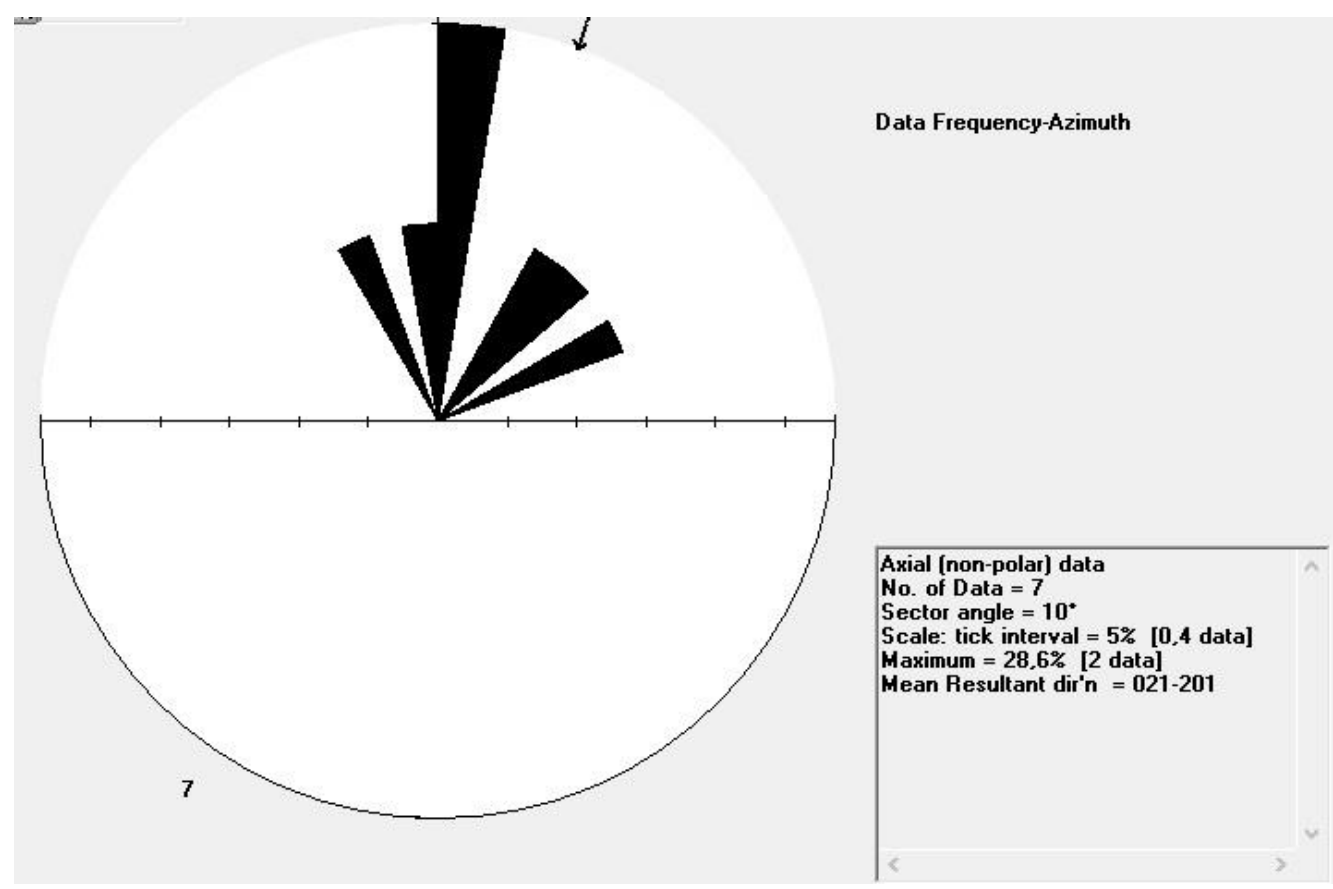

Fig. 11. A Rosetta diagram, drawn based on field measurements, indicates preferential paleoflows from South to North, along low sinuosity channels, suggesting the interpretation of a braided fluvial system.

\section{Acknowledgments}

The authors would like to thank State University of Rio de Janeiro - UERJ for funding and support given to fieldwork and to Cleveland M. Jones for the manuscript proofreading.

\section{References}

Arab, P.B., Perinotto, J.A.J., Assine, M.L., 2009. Grupo Itararé (P - C da Bacia do Paraná) nas regiões de Limeira e Piracicaba - SP: Contribuição ao Estudo das Litofácies. São Paulo, UNESP, Geociências 28 (4), 501-521.

Assine, M.L., Vesely, F.F. 2002. Ambientes Glaciais. In: Pedreira, A.J., Aragão, M.A.N.F., Magalhães, A.J., Testa, N. (eds.), Ambientes de Sedimentação do Brasil. Salvador, CPRM.

Assine, M.L., Vesely, F.F. 2008. Ambientes glaciais. In: Pedreira da Silva, A.J., Aragão, A.N.F., Magalhães, A.J.C (eds.), Ambientes de Sedimentação Siliciclástica do Brasil, Editora Beca, São Paulo, pp. 24-51.
Daemon, R.F., Quadros, L.P., 1970. Bioestratigrafia do Neopaleozóico da Bacia do Paraná. In: Anais do Congresso Brasileiro de Geologia, 24, 1970, Brasília, São Paulo: Sociedade Brasileira de Geologia.

França, A.B., Potter, P.E., 1988. Estratigrafia, ambiente deposicional e análise de reservatório do Grupo Itararé (Permocarbonífero), Bacia do Paraná (Parte 1). Boletim de Geociências da PETROBRAS, Rio de Janeiro, 2 (2- 4), 147-191. Folk, R. L., 1974, Petrology of Sedimentary Rocks: Hemphill Publishing Co., Austin, TX.

Gordon Jr., M.J., 1947. Classificação das formações gondwânicas do Paraná, Santa Catarina e Rio Grande do Sul. Notas Preliminares e Estudos da Divisão de Geologia e Mineralogia do DNPM, 38, 1-20.

Holz, M., França, A.B., Souza, P.A., Iannuzzi, R., Rohn, R., 2010. A stratigraphic chart of the Late Carboniferous/Permian succession of the eastern border of the Parana Basin, Brazil, South America. Journal of South American Earth Sciences, 29(2), 381-399. 
Mattos, N.H.S., 2012. Caracterização geológica e potencial para reservatórios no Grupo Itararé, na região Centro-leste do Estado de São Paulo. Instituto de Geociências, Universidade Estadual de Campinas, São Paulo, Trabalho de conclusão de curso, 72 pp.

Miall, A.D., 1978. Lithofacies types and vertical profile models of braided river deposits, a summary. In: Miall, A. D. (ed.), Fluvial Sedimentology. Canadian Society of Petroleum Geologists, Calgary, pp. 597-604.

Milani, E.J., Melo, J.H.G., Souza, P.A., Fernandes, L.A., França, A.B., 2007. Bacia do Paraná. In: Milani, E.J., Rangel, H.D., Bueno, G.V., Stica, J.M., Winter, W.R., Caixeta, J.M., Pessoa Neto, O.C. (eds.). Bacias Sedimentares Brasileiras - Cartas Estratigráficas. Boletim de Geociências da Petrobras, Rio de Janeiro 15(2), 265-287.
Suss, J.F., Vesely, F.F., Catharina, A. S. Assine, M.L., Paim, P.S.G., 2014. O Grupo Itararé (Neocarbonífero-Eopermiano) entre Porto Amazonas (PR) e Mafra (SC): sedimentação gravitacional em contexto marinho deltaico com influência glacial. Geociências, São Paulo, UNESP, 33, 701-719.

Vesely, F.F., 2006. Sistemas subaquosos alimentados por fluxos hiperpicnais gláciogênicos: modelo deposicional para arenitos do Grupo Itararé, Permocarbonífero da Bacia do Paraná. Boletim de Geociências da Petrobras, Rio de Janeiro, 15 (1), 7-25.

Vesely, F.F., Assine, M.L., 2004. Sequencias e tratos de sistemas deposicionais do Grupo Itararé, Norte do Estado do Paraná. Revista brasileira de Geociências 34 (2), 219-230. 